University of Nebraska - Lincoln

DigitalCommons@University of Nebraska - Lincoln

ET mapping for agricultural water management: present status and challenges

\author{
Prasanna H. Gowda \\ USDA-ARS, prasanna.gowda@ars.usda.gov \\ Jose L. Chavez \\ USDA-ARS, jose.chavez@colostate.edu \\ Paul D. Colaizzi \\ USDA-ARS, Paul.Colaizzi@ARS.USDA.GOV \\ Steven R. Evett \\ USDA-ARS, steve.evett@ars.usda.gov \\ Terry A. Howell \\ USDA-ARS, Terry.Howell@ars.usda.gov \\ See next page for additional authors
}

Follow this and additional works at: https://digitalcommons.unl.edu/usdaarsfacpub

Gowda, Prasanna H.; Chavez, Jose L.; Colaizzi, Paul D.; Evett, Steven R.; Howell, Terry A.; and Tolk, Judy A., "ET mapping for agricultural water management: present status and challenges" (2008). Publications from USDA-ARS / UNL Faculty. 1843.

https://digitalcommons.unl.edu/usdaarsfacpub/1843

This Article is brought to you for free and open access by the U.S. Department of Agriculture: Agricultural Research Service, Lincoln, Nebraska at DigitalCommons@University of Nebraska - Lincoln. It has been accepted for inclusion in Publications from USDA-ARS / UNL Faculty by an authorized administrator of DigitalCommons@University of Nebraska - Lincoln. 
Authors

Prasanna H. Gowda, Jose L. Chavez, Paul D. Colaizzi, Steven R. Evett, Terry A. Howell, and Judy A. Tolk 


\title{
ET mapping for agricultural water management: present status and challenges
}

\author{
Prasanna H. Gowda $\cdot$ Jose L. Chavez $\cdot$ \\ Paul D. Colaizzi · Steve R. Evett · Terry A. Howell • \\ Judy A. Tolk
}

Received: 22 March 2007 / Accepted: 16 July 2007 / Published online: 2 October 2007

(c) Springer-Verlag 2007

\begin{abstract}
Evapotranspiration (ET) is an essential component of the water balance. Remote sensing based agrometeorological models are presently most suited for estimating crop water use at both field and regional scales. Numerous ET algorithms have been developed to make use of remote sensing data acquired by sensors on airborne and satellite platforms. In this paper, a literature review was done to evaluate numerous commonly used remote sensing based algorithms for their ability to estimate regional ET accurately. The reported estimation accuracy varied from 67 to $97 \%$ for daily ET and above $94 \%$ for seasonal ET indicating that they have the potential to estimate regional ET accurately. However, there are opportunities to further improving these models for accurately estimating all energy balance components. The spatial and temporal remote sensing data from the existing set of earth observing satellite platforms are not sufficient enough to be used in the estimation of spatially distributed ET for on-farm irrigation management purposes, especially at a field scale level ( $\sim 10$ to 200 ha). This will be constrained further if the thermal sensors on future Landsat satellites are abandoned. However, research opportunities exist to improve the spatial and temporal resolution of ET by developing algorithms to increase the spatial resolution of reflectance and surface temperature data derived from Landsat/
\end{abstract}

Communicated by A. Kassam.

P. H. Gowda $(\bowtie)$ · J. L. Chavez · P. D. Colaizzi ·

S. R. Evett - T. A. Howell - J. A. Tolk

Conservation and Production Research Laboratory,

USDA-ARS, P.O. Drawer 10, Bushland, TX 79012, USA

e-mail: pgowda@cprl.ars.usda.gov
ASTER/MODIS images using same/other-sensor high resolution multi-spectral images.

\section{Introduction}

Evapotranspiration (ET) has been long been recognized as the most important process that plays an essential role in determining exchanges of energy and mass between the hydrosphere, atmosphere and biosphere (Sellers et al. 1996). In agriculture, it is a major consumptive use of irrigation water and precipitation on agricultural land. Any attempt to improve water use efficiency must be based on reliable estimates of ET, which includes water evaporation from land and water surfaces and transpiration by vegetation. ET varies regionally and seasonally according to weather and wind conditions (Hanson 1991). Understanding these variations in ET is essential for managers responsible for planning and management of water resources especially in arid and semi-arid regions of the world where crop water demand generally exceeds precipitation and requires irrigation from surface and/or groundwater resources to meet the deficit.

At a field scale, ET can be measured over a homogenous surface using conventional techniques such as Bowen ratio (BR), eddy covariance (EC) and lysimeter systems. However, these systems do not provide spatial trends (or distribution) at the regional scale especially in regions with advective climatic conditions. Remote sensing based ET models are better suited for estimating crop water use at a regional scale (Allen et al. 2007a). Numerous remote sensing-based ET algorithms that vary in complexity are available for estimating magnitude and trends in regional ET. This paper discusses remote sensing based regional ET 
prediction algorithms and their limitations, data needs and availability, knowledge gaps, and future opportunities and challenges with respect to agriculture.

\section{Remote sensing based ET algorithms}

Remote sensing has long been recognized as the most feasible means to provide spatially distributed regional ET information on land surfaces (Park et al. 1968; Jackson 1984; Choudhury et al. 1987). The use of remote sensing to estimate ET is presently being developed along two approaches: (a) land surface energy balance (EB) method that uses remotely sensed surface reflectance in the visible (VIS) and near-infrared (NIR) portions of the electromagnetic spectrum and surface temperature (radiometric) from an infrared (IR) thermal band, and (b) Reflectancebased crop coefficient (generally denominated $K_{\mathrm{cr}}$ ) and reference ET approach where the crop coefficient $\left(K_{\mathrm{c}}\right)$ is related to vegetation indices derived from canopy reflectance values. The first approach is based on the rationale that ET is a change of the state of water using available energy in the environment for vaporization (Su et al. 2005). Remote sensing based EB models convert satellite sensed radiances into land surface characteristics such as albedo, leaf area index, vegetation indices, surface emissivity and surface temperature to estimate ET as a "residual" of the land surface energy balance equation:

$\mathrm{LE}=R_{n}-G-H$

where, $R_{n}$ is the net radiation resulting from the budget of short and long wave incoming and emitted radiation respectively, LE is the latent heat flux from evapotranspiration, $G$ is the soil heat flux, and $H$ is the sensible heat flux (all in $\mathrm{W} \mathrm{m}^{-2}$ units). LE is converted to ET ( $\mathrm{mm} \mathrm{h}^{-1}$ or $\mathrm{mm} \mathrm{day}{ }^{-1}$ ) by dividing it by the latent heat of vaporization $\left(\lambda_{v} ; \sim 2.45 \mathrm{MJ} \mathrm{kg}^{-1}\right)$ and an appropriate time constant. $R_{n}$ and $G$ may be estimated locally using meteorological measurements (Allen et al. 1998) and regionally by incorporating spatially distributed reflected and emitted radiation (Jackson et al. 1985) as:

$R_{n}=(1-\alpha) R_{s}+\varepsilon_{\mathrm{a}} \sigma T_{\mathrm{a}}^{4}-\varepsilon_{\mathrm{s}} \sigma T_{s}^{4}$

where $\alpha$ is surface albedo, $R_{\mathrm{S}}$ is incoming short wave radiation $\left(\mathrm{W} \mathrm{m}^{-2}\right)$ measured with pyranometers or calculated using the Angstrom formula based on the solar constant, location and time of the year (Allen et al. 1998) or by using the solar constant, the cosine of the solar incidence angle, the inverse squared relative earth-sun distance, and atmospheric transmissivity based on the area of interest (image) ground elevation respect to mean sea level (Allen et al. 2007a), $\sigma$ is the Stefan-Boltzmann constant $\left(5.67 \mathrm{E}-08 \mathrm{~W} \mathrm{~m}^{-2} \mathrm{~K}^{-4}\right), \varepsilon$ is emissivity and $T$ temperature $(\mathrm{K})$ with subscripts "a" and " $\mathrm{s}$ " for air and surface, respectively. $T_{\mathrm{s}}$ is the remotely sensed radiometric surface temperature which is obtained after correcting the sensor brightness temperature imagery for atmospheric effects and for surface emissivity considering, for example, procedures by Hipps (1989) and Brunsell and Gillies (2002). The surface emissivity correction is performed assuming typical bare soil and fully vegetated surface emissivities of 0.93 and 0.98 , respectively, and the fractional vegetation cover from the scaled normalized difference vegetation index (NDVI). Alternatively, surface albedo for vegetated areas is generally estimated using the Brest and Goward (1987) model. This model is based on the red $(\mathrm{R})$ and NIR band reflectance:

$$
\alpha=0.512 R+0.418 \mathrm{NIR}
$$

The emissivity of air can be obtained from the Brutsaert (1975) equation:

$\varepsilon_{\mathrm{a}}=0.0172\left(\frac{e_{\mathrm{a}}}{T_{\mathrm{a}}}\right)^{1 / 7}$

where $e_{\mathrm{a}}$ is actual vapor pressure ( $\left.\mathrm{kPa}\right)$. $G$ is commonly estimated as a fraction of $R_{n}$ depending on leaf area index (LAI) or NDVI. Chávez et al. (2005) found that a combination of a linear and a logarithmic model could estimate $G$ for soils planted to corn and soybean crops in central Iowa $\left(r^{2}=0.73\right)$ :

$G=R_{n}(0.3324-0.024 \mathrm{LAI})(0.8155-0.3032 \mathrm{LN}(\mathrm{LAI}))$

$H$ is then estimated using the aerodynamic surface-air temperature gradient (or combination of gradients) and aerodynamic resistance, where generally radiometric temperature $\left(T_{\mathrm{s}}\right)$ has been used as a surrogate for aerodynamic temperature $\left(T_{\mathrm{o}}\right)$.

In the second approach, $R$ and NIR reflectance measurements are used to compute a vegetation index such as NDVI (Rouse et al. 1974) or the soil adjusted vegetation index (SAVI; Huete 1988), and the vegetation index is then used in place of calendar days or heat units to drive or scale the crop coefficient. The reference ET is then computed using local meteorological measurements of incoming solar radiation, air temperature, relative humidity or dew temperature, and wind speed.

Some early applications of remote sensing based EB models include Brown and Rosenberg (1973), Brown (1974), Stone and Horton (1974), Idso et al. (1975), Heilman et al. (1976), Verma et al. (1976), Kanemasu et al. (1977), and Jackson et al. (1977). Most of these studies used airborne scanners as first demonstrated by 
Bartholic et al. (1972). Price (1982), Seguin and Itier (1983), and Taconet et al. (1986) were among some of the first to use thermal data obtained from satellites to estimate ET. They proposed to use surface temperature derived from remotely sensed data to estimate regional ET in the form:

$\mathrm{LE}=R_{n}-G-\frac{\rho_{\mathrm{a}} C_{p}\left(T_{\mathrm{S}}-T_{\mathrm{a}}\right)}{r_{\mathrm{ah}}}$

where $\rho_{\mathrm{a}}$ is air density $\left(\mathrm{kg} \mathrm{m}^{-3}\right), C_{\mathrm{p}}$ is specific heat capacity of the air $\left(\mathrm{J} \mathrm{kg}^{-1} \mathrm{~K}^{-1}\right)$, and $r_{\mathrm{ah}}$ is aerodynamic resistance for heat transfer $\left(\mathrm{s} \mathrm{m}^{-1}\right) . T_{\mathrm{s}}$ and $T_{\mathrm{a}}$ are expressed in $K$. For example, Brown and Rosenberg (1973), and Brown (1974) used the surface radiometric temperature and air temperature difference, $\left(T_{\mathrm{s}}-T_{\mathrm{a}}\right)$, and the aerodynamic resistance $\left(r_{\text {ah }}\right)$ to estimate $H$ where the canopy or surface temperature was obtained from remotely sensed radiometric temperature using thermal scanners having a bandwidth mostly in the range of $10-12 \mu \mathrm{m}$. Later, Rosenberg et al. (1983) incorporated the term surface aerodynamic temperature $\left(T_{\mathrm{o}}\right)$ in the $H$ model, instead of surface radiometric temperature, considering that the temperature gradient (for $H$ ) was a gradient between air temperature within the canopy (at a height equal to the zero plane displacement plus the roughness length for heat transfer) and air temperature above the canopy (at a height where wind speed was measured or height for $r_{\mathrm{ah}}$ ). They indicated that for partially vegetated areas and for water stressed biomass, radiometric and aerodynamic temperatures of the surface were not equal. This inequality is discussed further in a later section.

Hatfield et al. (1983) evaluated the surface temperature with the energy balance approach at seven locations throughout the United States equipped with weighing lysimeters and ground-based instrumentation. In their study, daily $G$ was assumed negligible. Crops were sorghum, alfalfa, tomato and wheat at full cover, and tomato at $80 \%$ cover. They concluded that remotely sensed $T_{\mathrm{s}}$ may be used in the EB model to estimate regional ET. Estimated LE values, using atmosphere stability corrected aerodynamic resistances, were very closely matched to those measured by the lysimeters. Reginato et al. (1985) refined estimates of $R_{n}$ using reflected shortwave and emitted long wave measurements as outlined by Jackson et al. (1985). They also used ground-based instrumentation to estimate ET of wheat and achieved good agreement with lysimeters and neutron scattering. Later, Jackson et al. (1987) applied this procedure using an airborne radiometer and compared with BR measurements for cotton, alfalfa, and wheat with homogenous crop surfaces (full canopy with no contribution from soil background). Comparison of the remote sensing based LE estimates for 5 days with BR values resulted in a greatest difference of $12 \%$ while errors in daily ET estimates were less than $8 \%$ for 3 days and $25 \%$ on the other two. Moran et al. (1989) then applied this procedure using $R / \mathrm{NIR}$ (simple ratio) and thermal data from the Landsat Thematic Mapper (TM) satellite and reported agreement within $12 \%$ with the BR and airborne data from Jackson et al. (1987).

Accurate estimates of $H$ are very difficult to achieve, mainly when $T_{\mathrm{s}}$ is used instead of $T_{\mathrm{o}}$ and when atmospheric effects and surface emissivity are not considered properly. In such cases, $H$ prediction errors have been reported to be around $100 \mathrm{~W} \mathrm{~m}^{-2}$ (Chávez and Neale 2003; Matsushima 2000). Consequently, more recent EB models differ mainly in the manner that $H$ is estimated. These models included the two-source model (TSM; Norman et al. 1995; Kustas and Norman 1996; Chehbouni et al. 2001), where the energy balance of soil and vegetation are modeled separately and then combined to estimate total LE, surface energy balance algorithm for land (SEBAL; Bastiaanssen et al. 1998) that uses hot and cold pixels to develop an empirical temperature difference equation, and surface energy balance index (SEBI; Menenti and Choudhury 1993) based on the contrast between wet and dry areas. Other models include simplified surface energy balance index (S-SEBI; Roerink et al. 2000); surface energy balance system (SEBS; Su 2002); the excess resistance $\left(\mathrm{kB}^{-1}\right.$; Kustas and Daughtry 1990; Su 2002); the aerodynamic temperature parameterization models proposed by Crago et al. (2004) and Chávez et al. (2005); Beta ( $\beta$ ) approach (Chehbouni et al. 1996); and most recently ET mapping algorithm (ETMA; Loheide and Gorelick 2005) and Mapping Evapotranspiration with Internalized Calibration (METRIC $^{\text {TM}}$; Allen et al. 2002, 2005, 2007a). The sections below discuss the main models in detail.

SEBI, SEBS and S-SEBS: SEBI, proposed by Menenti and Choudhury (1993), is based on the crop water stress index (CWSI; Jackson et al. 1981) concept in which surface meteorological scaling of CWSI is replaced with planetary boundary layer (PBL) scaling. It uses the contrast between wet and dry areas appearing within a remotely sensed scene to derive ET from the relative evaporative fraction $\left(\Lambda_{\mathrm{r}}\right)$. It determines $\Lambda_{\mathrm{r}}$ by relating surface temperature observations to theoretical upper and lower bounds on the difference between surface and air temperature (Menenti et al. 2003). Evaporative fraction $(\Lambda)$, as utilized by Bastiaanssen et al. (1998), is defined as the ratio of latent heat flux to the available energy $\left(\mathrm{AE}=R_{n}-G\right)$ and is assumed to remain nearly constant during the day.

Surface energy balance system (Su 2002) was developed using the SEBI concept. It uses a dynamic model for thermal roughness (Su et al. 2001), bulk atmospheric similarity (BAS) (Brutsaert 1999) and Monin-Obukhov similarity (MOS) theories for regional ET estimation, and atmospheric surface layer (ASL) scaling for estimating ET 
at local scale. SEBS requires wet and dry boundary conditions to estimate $H$. Under dry conditions, the calculation of $H_{\text {dry }}$ is set to the available energy $\mathrm{AE}$ as evaporation becomes zero due to the limitation of water availability and $H_{\text {wet }}$ is calculated using the Penman-Monteith parameterization (Monteith 1965, 1981) as:

$H_{\text {wet }}=\mathrm{AE}-\frac{\left(\frac{\rho_{\mathrm{a}} C p}{r_{\text {ah }}}\right)\left(e_{\mathrm{s}}-\frac{e}{\gamma}\right)}{\left(1+\frac{\Delta}{\gamma}\right)}$

where $e$ is the actual vapor pressure $(\mathrm{kPa}), e_{\mathrm{s}}$ is the saturation vapor pressure $(\mathrm{kPa}), \gamma$ is the psychrometric constant $\left(\mathrm{kPa}^{\circ} \mathrm{C}^{-1}\right), \Delta$ is the rate of change of saturation vapor pressure with temperature $\left(\mathrm{kPa}^{\circ} \mathrm{C}^{-1}\right)$ and $r_{\mathrm{ah}}$ is the bulk surface external or aerodynamic resistance $\left(\mathrm{s} \mathrm{m}^{-1}\right)$ estimated under the assumption that the bulk internal resistance is zero. Finally, relative evaporative fraction $\left(\Lambda_{r}\right)$, evaporative fraction $(\Lambda)$ and LE for each pixel in the remote sensing image is calculated as:

$\Lambda_{r}=1-\frac{H-H_{\mathrm{wet}}}{H_{\mathrm{dry}}-H_{\mathrm{wet}}}$

$\Lambda=\frac{\Lambda_{r}\left(R_{\mathrm{n}}-G-H_{\mathrm{wet}}\right)}{R_{\mathrm{n}}-G}$

and

$\mathrm{LE}=\Lambda\left(R_{\mathrm{n}}-G\right)$

The evaporative fraction $\left(\Lambda=\mathrm{LE} /\left(R_{n}-\mathrm{G}\right)\right)$ is used in the estimation of LE because it is assumed to remain constant through out the day and can be obtained for short periods and be used for LE extrapolation to daily values. Brutsaert and Sugita (1992) presented the assumption that the partitioning of available energy (AE) into $H$ and LE is constant (self-preservation of the available energy partitioning) or that the evaporative fraction remains almost constant during the daytime. Zhang and Lemeur (1995) added that the evaporative fraction indicates how much of the available energy is used for ET and that the assumption that the instantaneous $\Lambda$ is representative of the daily energy partitioning, is an acceptable approximation for clear-sky conditions. Crago (2000) concluded that the $\Lambda$ has the tendency to be nearly constant during daytime, permitting the estimation of daytime evaporation from one or two estimates of the evaporative fraction during the middle of the day at the satellite overpass time.

Su et al. (2005) evaluated SEBS with two independent, high-quality datasets that were collected at a field scale during the soil moisture-atmosphere coupling experiment (SMACEX) in the Walnut Creek agricultural watershed near Ames, IA, USA. Meteorological and EC measurements from ten locations within the watershed were used to estimate and compare fluxes during a period of rapid vegetation growth and varied hydrometeorology. Results indicated that ET estimates from the SEBS were close to $85-90 \%$ of the measured ET values from EC systems for both corn and soybean surfaces. In the same study, regional fluxes were calculated using Landsat enhanced thematic mapper plus (ETM+) data for a clear day during the field experiment. Results at the regional scale showed that ET prediction accuracies were strongly related to crop type with improved ET estimates for corn surfaces compared to those of soybean. Differences between the observed and predicted ET values were approximately 5\%. Further, McCabe and Wood (2006) used thermal data from Landsat ETM+ $(60 \mathrm{~m})$, advanced spaceborne thermal emission and reflection radiometer (ASTER; $90 \mathrm{~m}$ ), and moderate resolution imaging spectrometer (MODIS; 1,020 m) sensors to independently estimate ET using SEBS. A high degree of consistency was observed between flux retrievals from ETM+ and ASTER data while MODIS data was unable to discriminate the influence of heterogeneity in land use at field scale. The main limitation with the SEBS is that it requires aerodynamic roughness height. Currently, several methods are available to estimate this variable using wind profile, vegetation index, and crop height $\left(h_{\mathrm{c}}\right.$ in $\left.\mathrm{m}\right)$ or by assigning nominal values based on the land use.

S-SEBI (Roerink et al. 2000) is a simplified method derived from SEBS to estimate surface fluxes from remote sensing data. Consequently, this model is based on $\Lambda$ and the contrast between the areas with extreme wet and dry temperature, $T_{\text {wet }}$ and $T_{\text {dry }}$, respectively. The instantaneous LE is calculated as:

$\mathrm{LE}_{i}=\Lambda_{i}\left(R_{n}-G\right)_{i}$

where the subscript " $i$ " means instantaneous. $\Lambda_{i}$ is expressed as:

$\Lambda_{i}=\frac{T_{\text {Dry }}-T_{S}}{T_{\text {Dry }}-T_{\text {Wet }}}$

$\Lambda_{i}$ is assumed constant through the day. Daily $\operatorname{LE}\left(\mathrm{LE}_{d}\right)$ is calculated as:

$\mathrm{LE}_{d}=\frac{\mathrm{LE}_{i} R_{n, d}}{\left(R_{n}-G\right)_{i}}$

where $R_{n, d}$ is daily net radiation ( $\mathrm{W} \mathrm{m}^{-2}$ ), can be estimated from a known relationship at solar noon as:

$C_{d, i}=\frac{R_{n, d}}{R_{n, i}}$ 
where $R_{n, i}$ is the instantaneous net radiation, and $\mathrm{C}_{d, i}$ is approximately $0.30( \pm 0.03)$ for summer months. Finally, $\mathrm{ET}_{d}$ can be estimated as:

$\mathrm{ET}_{d}=\frac{\Lambda_{i} C_{d, i} R_{n, i}}{\lambda^{v}}$

The disadvantage of this method may be that it requires extreme $T_{\mathrm{s}}$ values, which cannot always be found on every image. However, the major advantages are that it is a simpler method that does not need additional meteorological data and it does not require roughness length as in the case of SEBS. Gómez et al. (2005) used the $\Lambda$ concept based on S-SEBI for estimating $\mathrm{ET}_{i}$ and to extrapolate it to $\mathrm{ET}_{d}$. The method was applied using airborne sensor: PolDER (polarization and directionality of earth reflectance) and a thermal camera. Validation with a BR system showed LE estimation error of $26 \%$ and $1 \mathrm{~mm} \mathrm{day}^{-1}$ for $\mathrm{ET}_{\mathrm{d}}$ over corn, alfalfa, wheat and sunflower crops.

TSM: The TSM considers the energy balance of the substrate (e.g., soil) and vegetation components separately, and then combines these components to estimate total ET. Norman et al. (1995) and Kustas and Norman (1999) developed operational methodology to the two-source approach proposed by Shuttleworth and Wallace (1985) and Shuttleworth and Gurney (1990). This methodology generally does not require additional meteorological or information over single-source models; however, it requires some assumptions such as the partitioning of composite radiometric surface temperature into soil and vegetation components, turbulent exchange of mass and energy at the soil level, and coupling/decoupling of energy exchange between vegetation and substrate (i.e., parallel or series resistance networks). The energy exchange in the soilplant-atmosphere continuum is based on resistances to heat and momentum transport, and sensible heat fluxes are estimated by the temperature gradient-resistance system. Radiometric temperatures, resistances, sensible heat fluxes, and latent heat fluxes of the canopy and soil components are derived by iterative procedures constrained by composite, directional radiometric surface temperature, vegetation cover fraction, and maximum potential latent heat flux.

Kustas et al. (2004) applied TSM to Landsat TM and ETM+ images to evaluate the effect of sensor resolution on model output over corn and soybean fields in central Iowa. The pixel resolution was varied from 60-120, 240, and $960 \mathrm{~m}$. Comparison of flux estimates with tower-based and aircraft-based flux measurements indicate that the TSM performed reasonably well. Gonzalez-Dugo et al. (2006) compared an EB single-source model with TSM to evaluate their ability to estimate surface fluxes. They found that both methods performed well (RMSD less than $31 \mathrm{~W} \mathrm{~m}^{-2}$ ) in estimating the $H$ using calibrated Landsat TM imagery.
However, the TSM performed slightly better than the EB single source model with $r^{2}$ values of 0.87 and 0.94 for $H$ and LE estimates, respectively. The EB single source model produced $r^{2}$ values of 0.78 and 0.91 for $H$ and LE estimates, respectively. Colaizzi et al. (2006a) evaluated the TSM for alfalfa, corn, cotton, grain sorghum, soybeans, winter wheat, wheat stubble, and bare soil using large weighing lysimeters in Bushland, Texas. The TSM overestimated LE for smaller observed LE $\left(<|400| \mathrm{W} \mathrm{m}^{-2}\right)$ by up to $200 \mathrm{~W} \mathrm{~m}^{-2}$, but relative error improved for larger LE. Overall, RMSE ranged from $77 \mathrm{~W} \mathrm{~m}^{-2}$ for soybean to $135 \mathrm{~W} \mathrm{~m}^{-2}$ for winter wheat, and TSM performance was not influenced by regional advection.

Norman et al. (2000a, b) proposed a variation of the TSM called dual-temperature-difference (DTD) method using time rate of change in $T_{\mathrm{s}}$ and $T_{\mathrm{a}}$ to compute surface heat fluxes. This method reduced the effect of errors associated with radiometric calibration, emissivity variations, and use of non-local air temperature and wind speed data. Comparison of $H$ estimates from DTD method with that from original TSM indicated that the DTD method had potential for regional-scale applications using geo-stationary satellites (like GOES) data with a synoptic weather network. $H$ estimation errors were generally $<50 \mathrm{~W} \mathrm{~m}^{-2}$. The DTD approach was well suited for geostationary satellites with high temporal resolution but coarse $(4 \mathrm{~km})$ spatial resolution, and it conceivably could be applied to thermal pixel disaggregation schemes to improve spatial resolution such as those described in the below paragraph.

Using the TSM, Kustas et al. (2003) and Norman et al. (2003) developed a two-step approach called the Disaggregated Atmosphere Land EXchange Inverse model (DisALEXI) to combine low- and high-resolution remote sensing data to estimate ET on the 10-100 m scale without requiring local observations. The first step involves deriving surface fluxes from low spatial resolution but frequently available remote sensing data using a coupled TSM-ABL model known as ALEXI. The second step disaggregates those low spatial resolution surface flux estimates using vegetation index and surface temperature estimates derived from non-frequent high resolution remote sensing datasets. For example, one can derive average surface flux estimates from a 4-h repeat cycle GOES satellite data with a spatial resolution of $5 \mathrm{~km}$ and disaggregate into high spatial resolution flux maps using vegetation index and surface temperature data from Landsat $(30 \mathrm{~m})$ dataset with a repeat cycle of 16 days. They successfully demonstrated its application using data from the Southern Great Plains in central Oklahoma (Norman et al. 2003). The root mean square difference (RMSD) between remote sensing estimates of surface fluxes and ground-based measurements were within 10- 
$12 \%$. Similar results were reported by Anderson et al. (2007).

SEBAL: Bastiaanssen (1995) and Bastiaanssen et al. (1998, 2005) described SEBAL in detail. Briefly, SEBAL is essentially a single-source model that solves the EB for LE as a residual. $R_{n}$ and $G$ are calculated based on $T_{\mathrm{s}}$ and reflectance-derived values of albedo, vegetation indices, LAI and surface emissivity. $H$ is estimated using the bulk aerodynamic resistance model and a procedure that assumes a linear relationship between the aerodynamic surface temperature-air temperature difference (dT) and radiometric surface temperature $\left(T_{\mathrm{s}}\right)$ calculated from extreme pixels. Basically, extreme pixels showing cold and hot spots are selected to develop a linear relationship between $\mathrm{dT}$ and $T_{\mathrm{s}}$. At the cold pixel in the satellite imagery, $H$ is assumed non-existent i.e., $H_{\text {cold }}=0$ and at the hot pixel, LE is set to 0 which in turn allows to set $H_{\text {hot }}=\left(R_{n}-\mathrm{G}\right)_{\text {hot }}$. Then, $\mathrm{dT}_{\text {cold }}=0$ and $\mathrm{dT}_{\text {hot }}$ can be obtained by solving the bulk aerodynamic resistance equation for the hot pixel as:

$H=\rho_{\mathrm{a}} C_{P} \frac{d T}{r_{\mathrm{ah}}}$

After calculating dT at both cold and hot pixels, a linear relationship between $\mathrm{dT}$ and $T_{\mathrm{s}}$ is developed to estimate $H$ iteratively correcting $r_{\mathrm{ah}}$ for atmospheric stability. This is done applying the MOS theory. This step requires $T_{\mathrm{a}}$ and $\mathrm{u}$ measured at a weather station and a mechanism that extrapolates wind speed to a blending height of 100$200 \mathrm{~m}$. The dT artifice is expected to compensate for errors in surface temperature estimates due to atmospheric correction, and does not assume that radiometric and aerodynamic temperatures are equivalent.

SEBAL has been tested extensively in different parts of the world. Bastiaanssen et al. (2005) summarized SEBAL accuracy under several climatic conditions at both field and regional scales. For a range of soil wetness and plant community conditions, the typical accuracy at field scale was $85 \%$ for a single day and $95 \%$ for a seasonal scale. For large watersheds, on an annual basis, the ET prediction accuracy was up to $96 \%$. However, application of SEBAL by Trezza (2002) for a variety of crops in Kimberly, ID resulted in ET estimation errors ranging from 2.7 to $35 \%$ with an average error of $18.2 \%$.

$M_{\text {METRIC }}^{T M}$ : A full description of the METRIC ${ }^{\mathrm{TM}}$ can be found in Allen et al. $(2002,2005,2007$ a) who highlighted that METRIC ${ }^{\mathrm{TM}}$ uses remote sensing imagery in the visible, near-infrared and thermal portion of the electromagnetic spectrum along with ground-based horizontal wind speed and near surface dew point temperature measurements. This model is based on the SEBAL algorithm.
The main difference between SEBAL and METRIC ${ }^{\mathrm{TM}}$ is that the latter does not assumes $H=0$ or $\mathrm{LE}=R_{n}-\mathrm{G}$ at the wet pixel, instead a soil water budget is applied for the hot pixel to verify that ET is indeed zero and for the wet pixel, LE is set to $1.05 \mathrm{ET}_{r} \lambda_{v}$, where $\mathrm{ET}_{\mathrm{r}}$ is the hourly (or shorter time interval) tall reference (like alfalfa) ET calculated using the standardized ASCE Penman-Monteith equation. The second difference is that it selects extreme pixels purely in an agricultural setting whereby the cold pixel should have biophysical characteristics (e.g., $\left.h_{\mathrm{c}}, \mathrm{LAI}\right)$ similar to the reference crop (alfalfa). The third difference is that METRIC ${ }^{\mathrm{TM}}$ uses the alfalfa reference evapotranspiration fraction $\left(\mathrm{ET}_{\mathrm{r}} \mathrm{F}\right)$ mechanism to extrapolate instantaneous LE flux to daily ET rates instead of using the $\Lambda$. $\mathrm{ET}_{r} \mathrm{~F}$ is the ratio of $\mathrm{ET}_{i}$ (remotely sensed instantaneous ET) to the reference $\mathrm{ET}_{\mathrm{r}}\left(\mathrm{e} . \mathrm{g} ., \mathrm{mm} \mathrm{h}^{-1}\right.$ ) that is computed from weather station data at overpass time.

Tasumi et al. (2003) validated METRIC ${ }^{\mathrm{TM}}$ for various crops grown on weighing lysimeters located at the USDAARS laboratory in Kimberly, Idaho. Allen et al. (2007b, 2005) compared seasonal ET estimated for two agroecosystems in Idaho: an irrigated meadow in the Bear River Basin and a sugar beet field near Kimberly, using MET$\mathrm{RIC}^{\mathrm{TM}}$ with lysimeters measurements resulted in 4 and $1 \%$ errors, respectively; with ET overestimation errors as high as $10-20 \%$. Errors in predicted monthly ET at Montpelier, ID averaged $\pm 16 \%$ relative to a local lysimeter, although the difference for ET sums over a 4-month period was only $4 \%$, according to the authors. Chavez et al. (2007) applied METRIC $^{\mathrm{TM}}$ to the Texas High Plains using a Landsat 5 TM image acquired early in the cropping season. The performance of the METRIC ${ }^{\mathrm{TM}}$ was evaluated by comparing the predicted daily ET with values derived from a soil water budget at four different locations. ET estimates errors were below $15 \%$. The use of METRIC ${ }^{\mathrm{TM}}$ for the advective conditions of the Texas High Plains is promising; however, more evaluation is needed using lysimeter or well-calibrated Scintillometer derived ET measurements for different agroclimatological conditions.

ETMA: The ETMA proposed by Loheide and Gorelick (2005) is based on the surface energy budget and requires only local weather data including $G$ measurements and high-resolution airborne thermal imagery to estimate ET. It uses two surface temperature points, $T_{\mathrm{LE}}$ and $T_{\mathrm{H}}$, at which all of the turbulent heat flux is attributed to the LE and $H$, respectively, to develop linear relationships between surface temperature and instantaneous ET $\left(\mathrm{ET}_{i}\right)$ at specified times as follows:

$\mathrm{ET}_{i}=\mathrm{AE} \frac{\left(\frac{T_{H}-T_{S}}{T_{H}-T_{\mathrm{LE}}}\right)}{\lambda^{v}}$ 
At $H=0, T_{\mathrm{LE}}=T_{\mathrm{a}}$ and at $\mathrm{LE}=0$, the $T_{\mathrm{H}}$ is calculated as:

$T_{H}=\frac{\mathrm{AE}\left(r_{\mathrm{ah}}+r_{\mathrm{ex}}\right)}{\rho_{\mathrm{a}} C_{p}}+T_{\mathrm{a}}$

where $r_{\mathrm{ex}}$ is the excess resistance that is encountered for heat transfer compared to momentum transfer (Norman and Becker 1995). Daily ET will then be developed from two instantaneous ET maps using Penman-Montieth and JarvisStewart models and surface resistance. ETMA was intended for application at the local scale where $T_{\mathrm{a}}, u, h_{\mathrm{c}}, e$, and $T_{\text {soil }}$, are uniform in space. This model may not work well for regions subject to advective conditions or may not be applicable on regions with significant surface heterogeneity.

$E B$ methods based on relating $T_{o}$ to $T_{s}$ : Since $T_{\mathrm{o}}$ cannot be measured directly, it is usually derived by inverting some form of Eq. (6). Numerous studies have shown that $T_{\mathrm{s}}$ and $T_{\mathrm{o}}$ are neither equal nor do they have a unique relationship, as reviewed by Kustas et al. (2003, 2007). Kustas and Norman (1996) pointed out that the difference between $T_{\mathrm{S}}$ and $T_{\mathrm{o}}$ can be significant for relatively sparse vegetation cover (LAI < 1.5) and/or water stressed vegetation. Chehbouni et al. (1996) tried to compensate for the difference of these two temperatures by trying to relate $\left(T_{\mathrm{S}}-T_{\mathrm{o}}\right)$ to $\left(T_{\mathrm{s}}-T_{\mathrm{a}}\right)$ for grass and mesquite patches. They indicated that despite some scatters, especially for the mesquite site, the comparison showed that the $\left(T_{\mathrm{s}}-T_{\mathrm{o}}\right)$ increased as $T_{\mathrm{o}}$ increased. Their model assumed that the relationship was not linear. Their results allowed the formulating of sensible heat flux $(H)$ using $T_{\mathrm{s}}$ as:

$H=\rho_{\mathrm{a}} C_{p} \beta\left(\frac{T_{s}-T_{\mathrm{a}}}{r_{\mathrm{ah}}}\right)$

where,

$\beta=\frac{1}{\exp \left(\frac{L}{L-\text { LAI }}\right)-1}$

where $L$ is a site-specific empirical factor. In Chehbouni et al. (1996), $L$ was found to be 2.5 through least square regression. They calibrated the model for LAI values less than $1.0 \mathrm{~m}^{2} \mathrm{~m}^{-2}$. A similar study by Matsushima (2005) over a wide range of rice density (LAI ranged from 0.04 to 5.4) indicated that the variation of $\beta$ with LAI did not agree with the empirical parameterization proposed by Chehbouni et al. (1996). Instead, the author found that the logarithmic diurnal average of the thermal roughness lengths $\left(Z_{\mathrm{oh}}\right)$ was a function of LAI. While on the other hand, Colaizzi et al. (2004) compared $\left(T_{\mathrm{s}}-T_{\mathrm{a}}\right)$ with $\left(T_{\mathrm{o}}-T_{\mathrm{a}}\right)$ using weighing lysimeters planted with irrigated alfalfa, irrigated and dryland cotton, and dryland grain sorghum. They did not find a relationship between $\left(T_{\mathrm{s}}-T_{\mathrm{a}}\right)$ and $\left(T_{\mathrm{o}}-T_{\mathrm{a}}\right)$. They concluded that the difference might have been influenced by the different surface roughness of each crop type.

Zibognon et al. (2002) applied a land surface-atmosphere-radiometer model to convert $T_{\mathrm{s}}$ to an equivalent isothermal (or aerodynamic) temperature using data for one day at a grass site with LAI of 1.0. The model used variables that described the shape of the vertical foliage temperature profile. The model estimates were compared to the $T_{\mathrm{o}}$ reference values from the inversion of the MOS theory, obtaining good agreement. In this study, $T_{\mathrm{o}}$ over $T_{\mathrm{s}}$ resulted in an improvement by $3.6 \mathrm{~K}$.

Crago et al. (2004) suggested calibrating the bulk aerodynamic resistance equation (Rosenberg et al. 1983) to estimate $T_{\mathrm{o}}$, using estimated $H$ values with the analytical land-atmosphere-radiometer model (ALARM). The model assumed the foliage had an exponential vertical temperature profile. They indicated that the same profile was felt by the within-canopy turbulence. The ALARM converted radiometric surface temperatures into $T_{\mathrm{o}}$ called the equivalent radiometric isothermal surface temperature and then calculated $H$ using the MOS theory.

Chávez et al. (2005) linearly related aerodynamic temperature $\left(T_{\mathrm{o}}\right)$ to $T_{\mathrm{s}}$, LAI, $T_{\mathrm{a}}$ and $u$ for corn and soybean fields in central Iowa. The calibration equation resulted with an $r^{2}$ value of 0.77 . The linear expression is shown below:

$T_{\mathrm{o}}=0.534 T_{\mathrm{s}}+0.39 T_{\mathrm{a}}+0.244 \mathrm{LAI}-0.192 u+1.67$

where $T_{\mathrm{s}}$ and $T_{\mathrm{a}}$ are in ${ }^{\circ} \mathrm{C}$, LAI is in $\mathrm{m}^{2} \mathrm{~m}^{-2}$, and $\mathrm{u}$ is in $\mathrm{m} \mathrm{s}^{-1}$. EC systems were used to extract values for $u$ and $T_{\mathrm{a}}$. The model was found to be valid for a LAI range of 0.3-5.0 and $u$ values ranging from 1.5 to $7.3 \mathrm{~m} \mathrm{~s}^{-1} . T_{\mathrm{a}}$ was measured approximately at a height of $2 \mathrm{~m}$ for soybean and $3 \mathrm{~m}$ for corn.

The evaluation of the $T_{\mathrm{o}}$ model was performed with inverted values from measured $H$ using a different set of EC stations resulted in a mean bias error (MBE) and root mean square error (RMSE) values of 0.2 and $0.9^{\circ} \mathrm{C}$, respectively. The corresponding goodness of fit was $r^{2}=0.90$ which demonstrated the good agreement with measured values. The $T_{\mathrm{o}}$ model was used in the EB estimation of LE which was compared to EC measured values resulting in MBE and RMSE of -9.2 and $39.4 \mathrm{~W} \mathrm{~m}^{-2}$, respectively. The errors were well within the margin of errors of the LE from EC ground station measurements. The comparison of estimated with measured values was performed taking into account the heat fluxes footprint by means of heat flux source area models that incorporate the analytical solution to the diffusion-dispersion-advection equation. However, note that the $T_{\mathrm{o}}$ model was developed using data over corn and soybean fields having relatively homogeneous surface canopies under unstable atmospheric 
conditions. Therefore, the proposed model requires further evaluation over heterogeneous surfaces and/or under stable/neutral atmospheric conditions of semi-arid regions.

\section{Instantaneous to daily ET extrapolation}

This technique was first introduced by Jackson et al. (1983) to calculate a coefficient to convert one-time-of-day remote sensing based ET estimates to daily total ET. It required geographic latitude, day of year, and time of day and diurnal solar radiation and ET were described by a sine function. They compared ET estimates with lysimetrically determined daily total ET for four crops at five different locations. Results indicated that reliable estimates of daily ET from one-time-of-day measurements could be made for cloud free days. For cloudy days, the results were less reliable, but the authors suggested that estimates could be improved by considering the amount and temporal distribution of cloud cover. They added that the one-time-of-day measurements should be made within about $2 \mathrm{~h}$ of solar noon.

In a recent study on fully irrigated alfalfa, partially irrigated cotton, dryland grain sorghum and bare soil (tilled fallow sorghum), Colaizzi et al. (2006b) found that the $\mathrm{ET}_{\mathrm{r}} \mathrm{F}$ approach could scale instantaneous LE to daily ET more accurately for cropped surfaces compared with evaporative fraction $\left[\Lambda=\mathrm{LE} /\left(R_{n}-G\right)\right]$; however, $\Lambda$ gave slightly better prediction for bare soil. The authors used the standardized ASCE-PM grass reference ET $\left(\mathrm{ET}_{\mathrm{o}} \mathrm{F}\right)$ to scale daily ET from one-time-of-day $0.5 \mathrm{~h}$ ET data from a lysimeter. They found daily ET underestimation errors were within the $10 \%$ for ET $>6 \mathrm{~mm} \mathrm{day}^{-1}$, within $20 \%$ for ET values between 3.9 and $5.8 \mathrm{~mm} \mathrm{day}^{-1}$, and $>20 \%$ for ET values ranged $0.4-3.2 \mathrm{~mm} \mathrm{day}^{-1}$. In a airborne remote sensing study conducted in Walnut Creek watershed located south of Ames in central Iowa, Chavez and Neale (2007) compared evaporative fraction, the solar radiation method and the alfalfa and grass reference evapotranspiration fraction methods to extrapolate instantaneous to daily ET. Instantaneous ET estimates were made from aircraft imagery acquired at different times of the day. In the study area, plant available water was not a limiting factor and advection was not an issue. Results indicated that the $\Lambda$ method performed better than the other two methods when compared to daily ET values measured by several EC systems. Better results were obtained for flight overpasses from local Noon to close to 2:00 PM CST.

\section{Reflectance-based crop coefficient method}

Reflectance based crop coefficient method has been studied, among others, by Reginato et al. (1985), Neale et al. (1989,
2003), and Hunsaker et al. (2005). Furthermore, crop coefficients $\left(K_{\mathrm{c}}\right)$ have been related to vegetation indices such as PVI (Jackson et al. 1980; Heilman et al. 1982), NDVI (Bausch and Neale 1987; Neale et al. 1989), and SAVI (Bausch 1993; Neale et al. 1996). D’Urso and Santini (1996) attempted to derive the crop coefficient analytically from remote sensing estimated albedo, surface roughness, and aerodynamic resistance (from LAI). This method does not require knowledge of crop development stage.

$K_{\mathrm{c}}$ is defined by the ratio of the crop $\mathrm{ET}_{\mathrm{c}}$ to the reference crop ET (grass or alfalfa). According to Allen et al. (1998), $K_{\mathrm{c}}$ represents an integration of the effects of four characteristics that distinguish a given crop form the reference crop: crop height (affects aerodynamic resistance and vapor transfer), canopy-soil albedo (affects $R_{n}$ ), canopy resistance (to vapor transfer), and evaporation from soil. $K_{\mathrm{c}}$ is mainly directly derived from studies of the soil water balance determined from cropped fields or from lysimeters. $K_{\mathrm{c}}$ values are estimated under optimal agronomical conditions, i.e., no water stress, disease, weed/insect infestation, or salinity issues.

Neale et al. (1996), using multi-temporal airborne digital multi-spectral video imagery acquired over cotton crop through a growing season, obtained reflectance-based crop coefficients that were related to the SAVI. They maintained a water balance in the root zone of the cotton crop in three fields with ET estimates based on $K_{\mathrm{c}}$ derived using the spectral methods and $K_{\mathrm{c}}$ curves from FAO Paper No. 56 (Allen et al. 1998). Reflectance based $K_{\mathrm{c}}$ followed the actual cotton growth in the field. Their results indicated that the FAO's $K_{\mathrm{c}}$ procedure underestimated ET during the vegetative stage of growth and overestimated towards the latter in the cropping season. Based on a simulated irrigation schedule, they emphasized that water savings could have been up to $12 \%$. Similarly, Harikishan et al. (2006) used the basal crop coefficient $\left(K_{\mathrm{cb}}\right)$ approach to estimate the crop ET from a non-water limited soil-plant environment showing a dry soil surface and plants free of pest/ disease. They concluded that canopy reflectance-based crop coefficient is a practical and accurate indicator of the actual crop ET. They conducted root zone soil water balance simulations where the seasonal variations in the simulated soil water profiles in the root zone were compared to the actual soil water contents measured with a neutron probe. Results showed good agreement throughout the cropping season and validated the canopy reflectancebased crop coefficient for non-grain crops. A historical retrospective on the remote sensing based crop coefficients for ET can be found in Neale et al. (2003). They concluded that the remote sensing based crop coefficients can be accurately used for grain, non-grain and forage crops.

In Kenya, Michael and Bastiaanssen (2000) derived reflectance based crop coefficient $\left(K_{\mathrm{cr}}\right)$ from Landsat 
images using the simplified Priestley-Taylor equation for estimating crop ET. They obtained good results for unstressed crop where vapor pressure deficits remained within acceptable limits. Tasumi et al. (2005a, b, 2006) showed a method to estimate $K_{\mathrm{cr}}$ using a satellite-based EB model and a parameterization of $K_{\mathrm{cr}}$ (which in this case represented mean $K_{\mathrm{c}}$ ) using NDVI to obtain daily ET. With this method traditional $K_{\text {cr }}$ curves could be adjusted to reflect actual crop/weather/field/management conditions by shifting key crop development days (curve shifting) to better match the remote sensing based $K_{\mathrm{cr}}$ curve and to obtain improved ET estimates. With the parameterization of $K_{\mathrm{cr}}$ using NDVI, ET estimates for grass and sugar beets were compared to lysimeter measurements. The seasonal ET estimation errors for grass and sugar beets were 2 and 6\%, respectively. The method of calibration was region specific and did not need a land use map showing crop types.

On a different approach, Zhang and Wegehenkel (2006) developed a regional ET model that integrates the MODIS vegetation data (VIS, NIR reflectance) with the FAO-56 Penman-Monteith reference ET model, where $K_{\mathrm{c}}$ was estimated based on the crop $h_{\mathrm{c}}$ and fractional vegetation cover $\left(f_{\mathrm{c}}\right)$. Fractional vegetation cover was related to NDVI values and root depth to LAI through the season. Estimated seasonal ET was compared with ET by twelve lysimeters $\left(1 \mathrm{~m}^{2} \times 1.5 \mathrm{~m}\right.$ deep) in Berlin, Germany, resulting in an index of agreement above 0.87 and $R^{2}$ values higher than 0.59 .

In a semi-arid region of Morocco, Er-Raki et al. (2007) compared estimates of actual ET for winter wheat under different irrigation treatments; using $K_{\mathrm{cb}}$ values from the FAO-56 procedure, locally measured $K_{\mathrm{cb}}$, and $K_{\mathrm{cb}}$ and $f_{\mathrm{c}}$ derived from NDVI (reflectance values based on ground radiometer readings); with ET values derived from EC systems. At mid-season state, the $K_{\mathrm{cb}}$ values based on FAO-56 were found considerably less than the locally calibrated $K_{\mathrm{cb}}$ values. NDVI-based $K_{\mathrm{cb}}$ values were found acceptable especially when the soil evaporation was negligible suggesting that this method is promising for regional scale ET estimation. The locally developed $K_{\mathrm{cb}}$ values and the NDVI based values performed similarly with ET prediction errors of $0.16 \pm 0.45$ and $0.33 \pm 0.51 \mathrm{~mm} \mathrm{day}^{-1}$, respectively, producing a model efficiency of 79 and $70 \%$, respectively, compared to $44 \%$ with the FAO-56 procedure.

\section{Limitations and future challenges}

Radiometric versus aerodynamic temperature

It was recognized that radiometric temperature is sensitive to canopy structure (Kimes 1980), vertical vegetation temperature distribution (Kimes et al. 1980), and row spacing and soil-vegetation component temperatures (Kimes 1983), regardless of the type of platform used (i.e., ground, airborne, or satellite) or sensor characteristics (i.e., band pass response, field of view, internal calibration). Most single-source EB methods use radiometric temperature as a surrogate for $T_{\mathrm{o}}$ although they may not be equal. Greater differences between $T_{\mathrm{s}}$ and $T_{\mathrm{o}}$ may be found with larger BRs (i.e., when the sensible heat flux is much larger in proportion to latent heat flux), and with partial vegetation (Hatfield et al. 1984; Jackson et al. 1987) and dry or water stressed vegetation (Kustas et al. 1989; Kalma and Jupp 1990). Norman et al. (1995) and Norman and Becker (1995) pointed out that when two targets (e.g., soil and vegetation) at different temperature levels are viewed by the sensor, their composite wavelength distribution is not that of a blackbody, meaning that there is no equivalent composite blackbody giving the same radiance at the given temperature. Hence, equality of radiometric and aerodynamic temperature, at least for composite surfaces, should not be expected. Supporting these findings, Alves et al. (2000) found that radiometric surface temperature for dry conditions greatly depart from the aerodynamic temperature, which in turn will result in considerable errors in the estimation of sensible heat flux.

Spatial and temporal resolution

There is usually a trade-off between spatial (i.e., pixel size) and temporal (i.e., repeat frequency) resolution for satellite platforms (Table 1). For example, the Landsat 5 has a repeat cycle of 16 days with $30-120 \mathrm{~m}$ spatial resolution compared with daily coverage of MODIS with 250$1,000 \mathrm{~m}$. Furthermore, the spatial resolutions of thermal bands are often coarser than other wavelengths such as visible, NIR and SWIR (Shortwave-Infrared). For example, MODIS provides thermal images at 1,000-m resolution compared with $250-\mathrm{m}$ resolution for images acquired in other bandwidths on the same satellite platform.

The ET maps derived from remote sensing data acquired by satellite-based sensors with daily coverage such as MODIS, geostationary environmental satellite (GOES), and advanced very high resolution radiometer (AVHRR) are too coarse to be useful in agricultural regions because their pixel size is larger than individual fields in most regions causing significant errors in ET estimation (Tasumi et al. 2006). The spatial errors in the estimated ET are partly due to presence of pixels having multiple land uses/ vegetation types with significant differences in cover, roughness and/or moisture content (Kustas et al. 2004). This condition is more common in arid and semi-arid regions where fully irrigated fields are usually surrounded 
Table 1 Repeat cycle, spectral and spatial resolution of spectral bands on ASTER, Landsat 5, and MODIS sensors

\begin{tabular}{|c|c|c|c|c|}
\hline Satellite & $\begin{array}{l}\text { Repeat } \\
\text { cycle }\end{array}$ & $\begin{array}{l}\text { Spectral } \\
\text { band }\end{array}$ & $\begin{array}{l}\text { Wavelength } \\
(\mu \mathrm{m})\end{array}$ & $\begin{array}{l}\text { Spatial } \\
\text { resolution } \\
(\mathrm{m})\end{array}$ \\
\hline \multirow[t]{14}{*}{ ASTER } & \multirow[t]{14}{*}{16 days (nadir) } & 1 & $0.52-0.60$ (green) & \multirow[t]{3}{*}{15} \\
\hline & & 2 & $0.63-0.69$ (red) & \\
\hline & & 3 & $0.76-0.86$ (NIR) & \\
\hline & & 5 & $1.600-1.700$ (SWIR) & \multirow[t]{6}{*}{30} \\
\hline & & 6 & $2.145-2.185$ (SWIR) & \\
\hline & & 7 & $2.185-2.225$ (SWIR) & \\
\hline & & 8 & $2.235-2.285$ (SWIR) & \\
\hline & & 9 & $2.295-2.365$ (SWIR) & \\
\hline & & 10 & $2.360-2.430$ (SWIR) & \\
\hline & & 11 & $8.125-8.475$ (TIR) & \multirow[t]{5}{*}{90} \\
\hline & & 12 & $8.475-8.825$ (TIR) & \\
\hline & & 13 & $8.925-9.275$ (TIR) & \\
\hline & & 14 & $10.25-10.95$ (TIR) & \\
\hline & & 15 & $10.95-11.65$ (TIR) & \\
\hline \multirow[t]{7}{*}{$\mathrm{TM}$} & \multirow[t]{7}{*}{16 days } & 1 & $0.45-0.52$ (blue) & \multirow[t]{6}{*}{30} \\
\hline & & 2 & $0.52-0.60$ (green) & \\
\hline & & 3 & $0.63-0.69$ (red) & \\
\hline & & 4 & $0.76-0.90$ (NIR) & \\
\hline & & 5 & $1.55-1.75$ (SWIR) & \\
\hline & & 7 & 2.08-2.35 (SWIR) & \\
\hline & & 6 & $10.4-12.5$ (TIR) & 120 \\
\hline \multirow[t]{9}{*}{ MODIS } & \multirow[t]{9}{*}{ Daily } & 1 & $0.62-0.67$ (red) & \multirow[t]{2}{*}{250} \\
\hline & & 2 & $0.841-0.876$ (NIR) & \\
\hline & & 3 & $0.459-0.479$ (blue) & \multirow[t]{5}{*}{500} \\
\hline & & 4 & $0.545-0.565$ (green) & \\
\hline & & 5 & $1.230-1.250$ (SWIR) & \\
\hline & & 6 & $1.628-1.652$ (SWIR) & \\
\hline & & 7 & $2.105-2.155$ (SWIR) & \\
\hline & & 31 & $10.780-11.280$ (TIR) & \multirow[t]{2}{*}{1,000} \\
\hline & & 32 & $11.770-12.270$ (TIR) & \\
\hline
\end{tabular}

NIR Near infrared, SWIR shortwave infrared, TIR thermal infrared

by an extremely dry landscape. However, there is a research need to utilize simultaneously acquired high resolution visible, VNIR and SWIR images from the MODIS as well as data from other sensors such as ASTER and Landsat $5 \mathrm{TM}$ to scale up the ET maps (in terms of frequency and spatial resolution). Most likely a combination of data from satellites/airborne remote sensing platforms (temporally coinciding/not coinciding), ET pixels scaling algorithms, and in between overpasses interpolation techniques will contribute towards improving the spatial and temporal resolution issues. Limited research (McCabe and Wood 2006; Kustas et al. 2003, 2004 for the humid Iowa region; Jacob et al. 2002 for Mediterranean Region) has been done to evaluate the scale influences on the estimation of ET using multiple aircraft and satellite sensors. However, no such study has been implemented in semi-arid and arid regions of the U.S. to evaluate scale influences on estimating ET using land surface EB models.

Success of remote sensing based ET models depends on the availability cloud-free remote sensing data. In areas such as semi-arid Southern and Central High Plains in the central U.S., there is a limited opportunity to obtain cloud free data at high spatial resolution from satellite platforms such as Landsat and ASTER. In addition, Landsat 5 is expected to be out of service in 2008, and chances of having a thermal sensor on future Landsat satellites are presently low. However, there is a possibility to use microwave data to estimate surface fluxes through computation of soil and canopy temperatures (Trofleau et al. 1997). Numerous field studies with microwave data (Moran et al. 1997; Diak et al. 1995) indicate that low frequency $(\sim 5 \mathrm{GHz})$ microwave backscatter may be related to $\left(T_{\mathrm{s}}-T_{\mathrm{a}}\right)$ while high frequency $(\sim 15 \mathrm{GHz})$ microwave backscatter may be related to the NDVI. One main drawback at present with microwave data is that the spatial resolutions of passive microwave sensors are on the order of $10-100 \mathrm{~km}$ limiting their use to global scale applications. With the advent of improved algorithms, we may be able to use active microwave sensors that provide data at high spatial resolutions.

\section{Data accuracy}

One main drawback of existing EB methods such as METRIC, SEBAL, SEBS, SEBI, S-SEBI, and ETMA is that they rely on the presence of extreme $T_{\mathrm{s}}$ (hot and cold or dry and wet) pixels in the imagery. Without the presence of high water use crops in the imagery, these methods may under-scale the true potential surface temperature range, thus leading to errors in the spatial ET estimation. However, these methods eliminate the need for accurate atmospheric correction of remote sensing data and surface emissivity to estimate $H$ accurately. The TSM does not require identifying extreme temperature pixels and appears to perform very well over heterogeneous surfaces with daily ET estimate errors lower than $15 \%$. However, it requires numerous inputs/steps and atmospheric correction of images with atmosphere radiative transfer models and local radiosonde data. The magnitude of errors in the calibration of radiometric temperature values depends mainly on the availability and accuracy of local atmospheric relative humidity profile and visibility data close to the time of remote sensing data acquisition. Other errors with the EB models may relate to the spatial validity of weather station data such as air temperature, dew point temperature and wind speed in the highly advective arid and semi-arid 
regions as well as the sub-models used to derive LAI, crop height, fraction cover from remote sensing data.

\section{Data processing time and user friendliness}

Timeliness of information products derived from remotely sensed data remains an unresolved issue since Park et al. (1968) and others first envisioned remote sensing applications for agricultural management. This has been revisited numerous times during the intervening four decades (e.g., Jackson 1984; Moran 1994; Moran et al. 1997). To reiterate, the usefulness of remote sensing in the estimation of irrigation water demand will depend on the turn around time between image acquisition and the dissemination of derived ET information. At present, the turn around time is anywhere from 1 to 3 weeks depending on the remote sensing platform/sensor, algorithm utilized, and technician's experience/expertise on applying such algorithms. However, for most agricultural applications, ET maps should be delivered within hours, and almost instantaneous (i.e., real-time) timeliness is required for irrigation scheduling. Research should include programs geared towards rapid processing and analysis of remotely sensed imagery with the aid of artificial intelligence, to make ET maps readily available to producers, researchers, and the public by publishing daily digital ET maps over the Internet.

Review of different ET mapping algorithms presented in this paper show that most EB models are complex to use. Literature review indicated that there is an effort towards the simplification of the procedures to estimate regional ET mainly through the parameterization of crop coefficients using vegetation indices or the scaling of potential ET based on extreme surface temperature pixels. However, coefficients used in the simplified methods may vary spatially from one region to another. More research needs to be done in this direction, and some research efforts are presently underway to address the transferability of crop coefficients to different location (Howell et al. 2006).

\section{Model validation}

Literature review showed that most studies used BR and/or EC data for development and calibration of regional scale EB models. It is known that EC method has an energy balance non-closure problem i.e., $R_{n} \neq H+\mathrm{LE}+G$ (Oncley et al. 2000; Twine et al. 2000) of up to $20 \%$ even for non-advective conditions. Measurements of latent heat flux differed by up to $29 \%$ between BR and large, weighing lysimeters for irrigated alfalfa during advective conditions in the Southern High Plains of Texas (Todd et al. 2000). Therefore, calibration of the EB models against lysimetric and/or well-calibrated scintillometer measurements over irrigated and dryland conditions may enhance their ability to estimate regional ET accurately. In addition, heat flux source models should be utilized to properly weight and integrate LE pixels, for example, upwind of BR, EC, and/or scintillometer stations in the process of comparison of LE estimates with measured values (Chávez et al. 2005).

\section{Conclusions}

Reliable regional ET estimates are essential to improve spatial crop water management. Land surface EB models, using remote sensing data from ground to airborne to satellite platforms at different spatial resolutions, have been found to be promising for mapping daily and seasonal ET at a regional scale. In this paper, a thorough review of numerous remote sensing based models was made to understand the current status of the regional ET research, underlying principle for each method, data requirements, and their strengths and weaknesses. In all EB methods, thermal remote sensing data is one of the crucial inputs. In general, ET estimation errors associated with EB models were mostly found in the range of 2.7 $35 \%$ for daily ET and less than $6 \%$ for seasonal ET, with larger errors associated with simplified methods. Reflectance based crop coefficient methods are relatively easy to use to estimate ET compared to EB models, however, crop coefficients must account for water stress and require calibration for each crop type. Further, a major limitation of this approach is the spatial validity of the estimated reference ET.

Although the remote sensing based ET models shown to have the potential to accurately estimate regional ET, there are opportunities to further improve these models through (1) developing methods for accurately estimating canopy temperature profiles, (2) testing the spatial validity of the meteorological data such as air temperature and wind speed used in the EB models, and (3) testing the sub-models used to estimate soil heat flux, LAI, crop height, etc., for their accuracy, under various agrometeorological/environmental conditions. In addition, further evaluation of different scaling methods to extrapolate remote sensing derived instantaneous ET to daily and seasonal ET values is needed.

The spatial and temporal remote sensing data from existing set of earth observing satellite sensors are not sufficient to use their ET products for irrigation scheduling. This may be constrained further by the disappearance of thermal sensors on future Landsat satellites. However, research opportunities exist to improve the spatial and temporal resolution of ET by developing algorithms similar to those by McCabe and Wood (2006), Kustas et al. (2003), 
Norman et al. (2003), Kustas et al. (2004), or Jacob et al. (2002) to improve spatial resolution of reflectance and surface temperature data derived from Landsat/ASTER/ MODIS images using same/other-sensor high resolution visible, NIR and SWIR images. Finally, weighting and integrating remote sensing derived ET pixels should be done using footprint (heat flux source area) models for proper comparison to measured values by $\mathrm{EC}, \mathrm{BR}$ or scintillometer energy balance stations.

\section{References}

Allen R, Pereira L, Raes D, Smith M (1998) Crop evapotranspiration: guidelines for computing crop water requirements. FAO Irrigation and Drainage Paper No. 56. FAO, Rome

Allen RG, Tasumi M, Trezza R (2002) METRIC ${ }^{\mathrm{TM}}$ : mapping evapotranspiration at high resolution-application manual for Landsat satellite imagery. University of Idaho, Kimberly

Allen RG, Tasumi M, Morse A (2005) Satellite-based evapotranspiration by METRIC and Landsat for western states water management. US Bureau of Reclamation Evapotranspiration Workshop, Feb 8-10, 2005, Ft. Collins

Allen RG, Tasumi M, Trezza R (2007a) Satellite-based energy balance for mapping evapotranspiration with internalized calibration (METRIC)-Model. ASCE J Irrigation Drainage Eng (in press)

Allen RG, Tasumi M, Morse A, Trezza R, Wright JL, Bastiaanssen W, Kramber W, Lorite-Torres I, Robison CW (2007b) Satellitebased energy balance for mapping evapotranspiration with internalized calibration (METRIC)-applications. ASCE J Irrigation Drainage Eng (in press)

Alves I, Fontes JC, Pereira LS (2000) Evapotranspiration estimation from infrared surface temperature. I: Performance of the flux equation. Trans ASAE 43(3):591-598

Anderson CM, Kustas WP, Norman JM (2007) Upscaling flux observations from local to continental scales using thermal remote sensing. Agron J 99:240-254

Bartholic JF, Namken LN, Wiegand CL (1972) Aerial thermal scanner to determine temperatues of soils and of crop canopies differing in water stress. Agron J 64:603-608

Bastiaanssen WGM (1995) Regionalization of surface flux densities and moisture indicators in composite terrain: a remote sensing approach under clear skies in Mediterranean climates. PhD Dissertation, CIP Data Koninklijke Blibliotheek, Den Haag, The Netherlands

Bastiaanssen WGM, Menenti M, Feddes RA, Holtslang AA (1998) A remote sensing surface energy balance algorithm for land (SEBAL): 1. Formulation. J Hydrol 212-213:198-212

Bastiaanssen WGM, Noordman EJM, Pelgrum H, Davids G, Thoreson BP, Allen RG (2005) SEBAL model with remotely sensed data to improve water-resources management under actual field conditions. ASCE J Irrigation Drainage Eng 131(1):85-93

Bausch WC (1993) Soil background effects on reflectance-based crop coefficients for corn. Remote Sensing Environ 46:213-222

Bausch WC, Neale CMU (1987) Crop coefficients derived from reflectance canopy radiation: a concept. Trans ASAE 30(3):703709

Brest CL, Goward SN (1987) Driving surface albedo measurements from narrow band satellite data. Int J Remote Sensing 8:351-367

Brown KW (1974) Calculations of evapotranspiration from crop surface temperature. Department of Soil and Crop Science, College Station
Brown KW, Rosenberg NJ (1973) A resistance model to predict evapotranspiration and its application to a sugar beet field. Agron J 68:635-641

Brunsell NA, Gillies R (2002) Incorporating surface emissivity into a thermal atmospheric correction. Photogrammetric Eng Remote Sensing J 68(12):1263-1269

Brutsaert W (1975) On a derivable formula for long-wave radiation from clear skies. Water Resources Res 11:742-744

Brutsaert W (1999) Aspect of bulk atmospheric boundary layer similarity under free-convective conditions. Rev Geophys 37:439-451

Brutsaert W, Sugita M (1992) Application of self-preservation in the diurnal evolution of the surface energy budget to determine daily evaporation. J Geophys Res 97:18377-18382

Chávez JL, Neale CMU (2003) Validating airborne multispectral remotely sensed heat fluxes with ground energy balance tower and heat flux source area (footprint) functions. ASAE Paper No. 033128. St. Joseph, Michigan

Chávez JL, Neale CMU, Hipps LE, Prueger JH, Kustas WP (2005) Comparing aircraft-based remotely sensed energy balance fluxes with eddy covariance tower data using heat flux source area functions. J Hydrometeorol AMS 6(6):923-940

Chavez JL, Neale CMU (2007) Daily evapotranspiration estimates from airborne remote sensing and ground data inputs. Trans ASABE (submitted)

Chavez JL, Gowda PH, Evett SR, Colaizzi PD, Howell TA, Marek T (2007) An application of METRIC for ET mapping in the Texas high plains. Trans ASABE (submitted)

Chehbouni A, Lo Seen D, Njoku EG, Monteny B (1996) Examination of the difference between radiative and aerodynamic surface temperatures over sparsely vegetated surfaces. Remote Sensing Environ 58:177-186

Chehbouni A, Nouvellon Y, Lhomme J-P, Watts C, Boulet G, Kerr YH, Moran MS, Goodrich DC (2001) Estimation of surface sensible heat flux using dual angle observations of radiative surface temperature. J Agric Forest Meteorol 108:55-65

Choudhury FJ, Idso SB, Reginato RJ (1987) Analysis of an empirical model for soil heat flux under a growing wheat crop for estimating evaporation by an infrared-temperature based energy balance equation. Agric Forest Meteorol 39:283-297

Colaizzi PD, Evett SR, Howell TA, Tolk JA (2004) Comparison of aerodynamic and radiometric surface temperature using precision weighing lysimeters. In: Gao W, Shaw DR (eds) Proceedings of SPIE 49th annual meeting, remote sensing and modeling of ecosystems for sustainability, vol 5544, pp 215-229

Colaizzi PD, Evett SR, Howell TA, Tolk JA (2006a) Comparison of five models to scale daily evapotranspiration from one-time-ofday measurements. Trans ASABE 49(5):1409-1417

Colaizzi PD, Evett SR, Howell TA, Tolk JA, Li F (2006b) Evaluation of a two-source balance model in an advective environment. Proc. World Enviromental and Water Resources Congress. May 21-24, 2006. Omaha, NE. EWRI, ASCE (CD-ROM)

Crago RD (2000) Conservation and variability of the evaporative fraction during the daytime. J Hydrol 180(1-4):173-194

Crago R, Friedl M, Kustas W, Wang Y (2004) Investigation of aerodynamic and radiometric land surface temperatures. NASA Scientific and Technical Aerospace Reports (STAR) 42(1)

Diak GR, Rabin RM, Gallo KP, Neale CM (1995) Regional scale comparisons of NDVI, soil moisture indices from surface and microwave data and surface energy budgets evaluated from satellite and in-situ data. Remote Sensing Rev 12:355-382

D'Urso G, Santini A (1996) A remote sensing and modeling integrated approach for the management of irrigation distribution systems. In: Proceedings of the international conference on "Evapotranspiration and Irrigation Scheduling", San Antonio (USA), vol 4-6, pp 435-441 
Er-Raki S, Chehbouni A, Guemouria N, Duchemin B, Ezzahar J, Hadria R (2007) Combining FAO-56 model and ground-based remote sensing to estimate water consumptions of wheat crops in a semi-arid region. Agric Water Manage 87:41-54

Gómez M, Olioso A, Sobrino JA, Jacob F (2005) Retrieval of evapotranspiration over the Alpille/ReSeDA experimental site using airborne POLDER sensor and a thermal camera. Remote Sensing Environ 96:399-408

Gonzalez-Dugo MP, Neale CMU, Mateos L, Kustas WP, Li F (2006) Comparison of remotely sensing-based energy balance methods for estimating crop evapotranspiration. In: Owe M, D'Urso G, Christopher Neale MU, Gouweleeuw BT (eds) Proceeding of SPIE, vol 6359: remote sensing for agriculture, ecosystems, and hydrology VIII, p 6359Z

Hanson RL (1991) Evapotranspiration and droughts. In: Paulson RW, Chase EB, Roberts RS, Moody DW, Compilers, National Water Summary 1988-89-hydrologic events and floods and droughts: U.S. Geological Survey Water-Supply Paper 2375, pp 99-104

Harikishan J, Neale CMU, Wright JL (2006) Development and validation of canopy reflectance based crop coefficient for potato. Agric Water Manage (in press)

Hatfield JL, Perrier A, Jackson RD (1983) Estimation of evapotranspiration at on time-of-day using remotely sensed surface temperatures. Agric Water Manage 7:341-350

Hatfield JL, Reginato RJ, Idso SB (1984) Evaluation of canopy temperature-evapotranspiration model over various crops. Agric Forest Meteorol 32:41-53

Heilman JL, Kanemasu ET, Rosenberg NJ, Blad BL (1976) Thermal scanner measurements of canopy temperatures to estimate evapotranspiration. Remote Sensing Environ 5:137-145

Heilman JL, Heilman WE, Moore DG (1982) Evaluating the crop coefficient using spectral reflectance. Agron J 74:967-971

Hipps LE (1989) The infrared emissivities of soil and Artemisia tridentate and subsequent temperature corrections in a shrubsteppe ecosystem. Remote Sensing Environ 27:337-342

Howell TA, Evett SR, Tolk JA, Copeland KS, Dusek DA, Colaizzi PD (2006) Crop coefficients developed at Bushland, Texas for corn, wheat, sorghum, soybean, cotton, and alfalfa. In: Proceedings of 2006 ASCE-EWRI World Water and Environmental Resources Congress, 21-25 May, Omaha

Huete A (1988) A soil adjusted vegetation index (SAVI). Remote Sensing Environ 25:295-309

Hunsaker DJ, Barnes EM, Clarke TR, Fitzgerald GJ, Pinter PJ Jr (2005) Cotton irrigation scheduling using remotely sensed and FAO-56 basal crop coefficients. Trans ASAE 48(4):1395-1407

Idso SB, Schmugge TJ, Jackson RD, Raginato RJ (1975) The utility of surface temperature measurements for the remote sensing of the soil water status. J Geophys Res 80:3044-3049

Jackson RD (1984) Remote sensing of vegetation characteristics for farm management. SPIE 475:81-96

Jackson RD, Reginato RJ, Idso SB (1977) Wheat canopy temperature: a practical tool for evaluating water requirements. Water Resour Res 13:651-656

Jackson RD, Idso SB, Reginato RJ, Pinter PJ (1980) Remotely sensed crop temperatures and reflectances as inputs to irrigation scheduling. In: Proceedings of American Society of Civil Engineers, Irrigation and Drainage Division, Specialty Conference, Boise, Idaho, pp 390-397

Jackson RD, Idso SB, Reginato RJ, Pinter PJ Jr (1981) Canopy temperature as a crop water stress indicator. Water Resour Res 17(4):1133-1138

Jackson RD, Hatfield JL, Reginato RJ, Idso SB, Pinter PJ Jr (1983) Estimation of daily evapotranspiration from one time-of-day measurements. Agric Water Manage 7:351-362
Jackson RD, Pinter PJ Jr, Reginato RJ (1985) Net radiation calculated from remote and multispectral and ground station meteorological data. Agric Forest Meteorol 35:153-164

Jackson RD, Moran MS, Gay LW, Raymond LH (1987) Evaluating evaporation from field crops using airborne radiometry and ground-based meteorological data. Irrigation Sci 8:81-90

Jacob F, Olioso A, Gu XF, Su A, Seguin B (2002) Mapping surface fluxes using airborn visible, near infrared remote sensing data and a spatialized surface energy balance model. Agronomie 22:669-680

Kalma JD, Jupp DLB (1990) Estimating evaporation from pasture using infrared thermometry: evaluation of a one-layer resistance model. Agric Forest Meteorol 51:223-246

Kanemasu ET, Stone LR, Powers WL (1977) Evapotranspiration model tested for soybeans and sorghum. Agron J 68:569-572

Kimes DS (1980) Effects of vegetation canopy structure on remotely sensed canopy temperatures. Remote Sensing Environ 10:165174

Kimes DS (1983) Dynamics of directional reflectance factor distributions for vegetation canopies. Appl Opt 22(9):1364-1372

Kimes DS, Smith JA, Ranson KJ (1980) Vegetation reflectance measurements as a function of solar zenith angle. Photogrammetric Eng Remote Sensing 46:1563-1573

Kustas WP, Daughtry CST (1990) Estimation of the soil heat flux/net radiation ratio from multispectral data. Agric Forest Meteorol 49:205-223

Kustas WP, Norman JM (1996) Use of remote sensing for evapotranspiration monitoring over land surfaces. Hydrol Sci J 41(4):495-516

Kustas WP, Norman JM (1999) Evaluation of soil and vegetation heat flux predictions using a simple two-source model with radiometric temperatures for partial canopy cover. Agric Forest Meteorol 94:13-29

Kustas WP, Choudhury BJ, Moran MS, Reginato RJ, Jackson RD, Gay LW, Weaver HL (1989) Determination of sensible heat flux over sparse canopy using thermal infrared data. Agric Forest Meteorol 44:197-216

Kustas WP, French AN, Hatfield JL, Jackson TJ, Moran MS, Rango A, Ritchie JC, Schumgge TJ (2003) Remote sensing research in Hydrometeorology. Photogrammetric Eng Remote Sensing 69(6):631-646

Kustas WP, Li F, Jackson TJ, Prueger JH, MacPherson JI, Wolde M (2004) Effects of remote sensing pixel resolution on modeled energy flux variability of croplands in Iowa. Remote Sensing Environ 92:535-547

Kustas WP, Anderson MA, Norman JM, Li F (2007) Utility of radiometric-aerodynamic temperature relations for heat flux estimation. Boundary-Layer Meteorol 122:167-187

Loheide II SP, Gorelick SM (2005) A local-scale, high resolution evapotranspiration mapping algorithm (ETMA) with hydroecological applications at riparian meadow restoration sites. Remote Sensing Environ 98:182-200

Matsushima D (2000) An estimation method for regional sensible heat flux on vegetation using satellite infrared temperature. In: Proceedings of the 15th conference of hydrology/80th AMS annual meeting, P1.29. Long Beach

Matsushima D (2005) Relations between aerodynamic parameters and heat transfer and thermal-infrared thermometry in the bulk surface formulation. J Meteorol Soc Jpn 83(3):373-389

McCabe MF, Wood EF (2006) Scale influences on the remote estimation of evapotranspiration using multiple satellite sensors. Remote Sensing Environ 105:271-285

Menenti M, Choudhury BJ (1993) Parameterization of land surface evapotranspiration using a location dependent potential evapotranspiration and surface temperature range. In: Bolle $\mathrm{HJ}$ et al 
(eds) Proceedings of exchange processes at the land surface for a range of space and time scales. IAHS Publ 212, pp 561-568

Menenti M, Jia L, Su Z (2003) On SEBI-SEBS validation in France, Intaly, Spain, USA and China. In: Co-Chair Allen RG, Bastiaanssen W (eds) Proceedings of the workshop on use of remote sensing of crop evapotranspiration for large regions. International Commission on Irrigation and Drainage (ICID), Montpellier

Micheal MG, Bastiaanssen WGM (2000) A new simple method to determine crop coefficients for water allocation planning from satellites: results from Kenya. Irrigation Drainage Syst 14:237256

Monteith JL (1965) Evaporation and environment. Symp Soc Explor Biol 19:205-234

Monteith JL (1981) Evaporation and surface temperature. Quart J R Meteorol Soc 107:1-27

Moran MS (1994) Irrigation management in Arizona using satellites and airplanes. Irrigation Sci 15(1):35-44

Moran MS, Jackson RD, Raymond LH, Gay LW, Slater PN (1989) Mapping surface energy balance components by combining Landsat Thematic Mapper and ground-based meteorological data. Remote Sensing Environ 30:77-87

Moran MS, Vidal A, Troufleau D, Qi J, Clarke TR, Pinter PJ Jr, Mitchell TA, Inoue Y, Neale CMU (1997) Combining multifrequency microwave and optical data for crop management. Remote Sensing Environ 61:96-109

Neale CMU, Bausch WC, Heeremann DF (1989) Development of reflectance-based crop coefficients for corn. Trans ASAE 32(6):1891-1899

Neale CMU, Ahmed RH, Moran MS, Pinter PJ, Qi J, Clarke TR (1996) Estimating seasonal cotton evapotranspiration using canopy reflectance. In: Camp CR, Sadler EJ, Yoder RE (eds) Evapotranspiration and irrigation scheduling: proceedings of the international conference, November 3-6, 1996. San Antonio. St. Joseph, Michigan, pp 173-181

Neale CMU, Jayanthi H, Wright JL (2003) Crop and irrigation water management using high resolution airborne remote sensing. In: Proceedings of 54th IEC meeting of the international commission on irrigation and drainage (ICID) workshop remote sensing of ET for large regions, 17 Sept (2003) Montpellier, France. CD-ROM. New Delhi, India

Norman JM, Becker F (1995) Terminology in thermal infrared remote sensing of natural surfaces. Agric For Meteorol 77:153-166

Norman JM, Kustas WP, Humes KS (1995) A two-source approach for estimating soil and vegetation energy fluxes from observations of directional radiometric surface temperature. Agric For Meteorol 77:263-293

Norman JM, Kustas WP, Prueger JH, Diak GR (2000a) Surface flux estimation using radiometric temperature: a dual temperature difference method to minimize measurement error. Water Resour Res 36:2263-2274

Norman JM, Kustas WP, Prueger JH, Diak GR (2000b) Surface flux estimation using radiometric temperature: dual-temperaturedifference method to minimize measurement errors. Water Resour Res 36(8):2263-2274

Norman JM, Anderson MC, Kustas WP, French AN, Mecikalski J, Torn R, Diak GR, Schmugge TJ, Tanner BCW (2003) Remote sensing of surface energy fluxes at 101-m pixel resolutions. Water Resour Res 39(8):1221

Oncley SP, Foken T, Vogt R, Bernhofer C, Liu H, Sorbjan Z Pitacco A, Grantz D, Ribeiro L (2000) The EBEX 2000 field experiment. In: 14th Symposium on boundary layers and turbulence, Aspen. American Meteorological Society, Boston, pp 322-324

Park AB, Colwell RN, Meyers VF (1968) Resource survey by satellite; science fiction coming true. Yearbook of Agriculture, pp 13-19
Price JC (1982) Estimation of regional scale evapotranspiration through analysis of satellite thermal-infrared data. IEEE Trans Geosci Remote Sens GE-20:286-292

Reginato RJ, Jackson RD, Pinter PJ Jr (1985) Evapotranspiration calculated from remote multi-spectral and ground station meteorological data. Remote Sensing Environ 18:75-89

Roerink GJ, Su B, Menenti M (2000) S-SEBI A simple remote sensing algorithm to estimate the surface energy balance. Phys Clim Earth (B) 25(2):147-157

Rosenberg NJ, Blad BL, Verma SB (1983) Microclimate, the biological environment, 2nd edn. Wiley, New York, 495p

Rouse JW, Haas RH Jr, Schell JA, Deering DW (1974) Monitoring vegetation systems in the Great Plains with ERTS. In: Proceedings of the ERTS-1 3rd Symposium, vol 1. NASA SP-351. NASA, Washington, pp 309-317

Seguin B, Itier B (1983) Using midday surface temperature to estimate daily evapotranspiration from satellite thermal data IR. Int J Remote Sensing 4(2):371-383

Sellers PJ, Randall DA, Collatz GJ, Berry JA, Field CB, Dazlich DA, Zhang C, Collelo GD, Nounoua L (1996) A revised land surface parameterization (SiB2) for atmospheric GCMS, Part 1: Model formulation. J Clim 9:676-705

Shuttleworth WJ, Gurney RJ (1990) The theoretical relationship between foliage temperature and canopy resistance in sparse crops. Quart J R Meteorol Soc 116:497-519

Shuttleworth WJ, Wallace JS (1985) Evaporation from sparse cropsan energy combination theory. Quart J Roy Meteorol Soc 111:839-855

Stone LR, Horton ML (1974) Estimating evapotranspiration using canopy temperatures: field evaluation. Agron J 66:450-454

$\mathrm{Su} \mathrm{Z}$ (2002) The surface energy balance system (SEBS) for estimation of turbulent fluxes. Hydrol Earth Syst Sci 6:85-99

Su Z, Schmugge T, Kustas WP, Massman WJ (2001) An evaluation of two models for estimation of the roughness height for heat transfer between the land surface and the atmosphere. J Appl Meteorol 40:1933-1951

Su H, McCabe MF, Wood EF, Su Z, Prueger JH (2005) Modeling evapotranspiration during SMACEX: comparing two approaches local- and regional-scale prediction. J Hydrometerol 6(6):910 922

Taconet O, Bernard R, Vidal-Madjar D (1986) Evapotranspiration over an agricultural region using a surface flux/temperature model based on NOAA-AVHRR data. J Clim Appl Meteorol 25:284-307

Tasumi M, Trezza R, Allen RG, Wright JL (2003) U.S. Validation tests on the SEBAL model for evapotranspiration via satellite. In: Proceedings of 54th IEC meeting of the international commission on irrigation and drainage (ICID) Workshop remote sensing of ET for large regions, 17 Sept (2003) Montpellier, France

Tasumi M, Trezza R, Allen RG, Wright JL (2005a) Operational aspects of satellite-based energy balance models for irrigated crops in the semi-arid U.S. J Irrigation Drainage Syst 19:355376

Tasumi M, Allen RG, Trezza R, Wright JL (2005b) Satellite-based energy balance to assess within-population variance of crop coefficient curves. ASCE J Irrigation Drainage Eng 131(1):94109

Tasumi M, Allen RG, Trezza R (2006) Calibrating satellite-based vegetation indices to estimate evapotranspiration and crop coefficients. In: Wichelns D, Anderson SS (eds) Proceedings of the 2006 USCID Water Management Conference. Ground water and surface water under stress: competition, interaction, solutions. Publisher USCID, Denver

Todd RW, Evett SR, Howell TA (2000) The Bowen ratio-energy balance method for estimating latent heat flux of irrigated alfalfa 
evaluated in a semi-arid, advective environment. Agric Forest Meteorol 103:335-348

Trezza R (2002) Evapotranspiration using a satellite-based surface energy balance with standardized ground control. PhD Disseration, Biological and Irrigation Engineering Department, Utah State University, Logan

Trofleau D, Vidal A, Beaudon A, Moran MS, Weltz MA, Goodrich DC, Washburne J, Rahman AF (1997) Optical-microwave synergy for estimating surface sensible heat flux over a semiarid rangeland. Remote Sensing Rev 15:113-132

Twine TE, Kustas WP, Norman JM, Cook DR, Houser PR, Meyers TP, Prueger JH, Starks PJ, Wesley ML (2000) Correcting eddycovariance flux underestimates over grassland. Agric Forest Meteorol 103:279-300
Verma SB, Rosenberg NJ, Blad BL, Baradas MW (1976) Resistanceenergy balance method for predicting evapotranspiration: determination of boundary layer resistance and evaluation of error effects. Agron J 68:776-782

Zibognon M, Crago R, Suleiman A (2002) Conversion of radiometric to aerodynamic surface temperature with an anishothermal canopy model. Water Resour Res 38(6): 1067

Zhang L, Lemeur R (1995) Evaluation of daily ET estimates from instantaneous measurements. Agric Forest Meteorol 74:139-154

Zhang Y, Wegehenkel M (2006) Integration of MODIS data into a single model for the spatial distributed simulation of soil water content and evapotranspiration. Remote Sensing Environ 104:393-408 